\title{
Effect of diet on lipid profile in HIV-infected patients
}

\author{
Agata Jackiewicz, Marcin Czarnecki, Brygida Knysz \\ Department of Infectious Diseases, Liver Diseases and Acquired Immune Deficiences, Wroclaw Medical University, Poland
}

\begin{abstract}
The implementation of highly active antiretroviral therapy has increased the life expectancy of people living with human immunodeficiency virus (HIV), thus reducing the number of deaths from acquired immune deficiency syndrome. Nowadays life expectancy of $\mathrm{HIV}(+)$ patients is comparable to those who are not infected. However, due to the use of antiretroviral therapy and the persistent immune activation and inflammation caused by HIV, other negative events may occur including dyslipidaemias, cardiovascular disorders, chronic kidney disease, early ageing, and neurocognitive impairment. It also increases the risk of developing metabolic syndrome and becomes a risk factor for cardiovascular disease: e.g. hypertension, brain stroke, and heart infarct. Comprehensive care of HIV patients with disturbed lipid profile includes lifestyle modifications such as dietary changes along with smoking cessation and has a beneficial effect on the lipid profile (total cholesterol, LDL, HDL, triglyceride levels). Therefore, it can reduce the risk of cardiovascular disease, allows the patients to avoid additional pharmacotherapy, and can eliminate drug-drug interactions with antiretroviral drugs.

There are a lot of data showing that early dietary intervention and consistent diet control have a beneficial effect on lipid disorders in HIV-infected patients. Clinicians should be aware of it. In view of the benefits that can be gained by people living with HIV from dietary intervention, it is appropriate to include dieticians in a panel of specialists who take care of $\mathrm{HIV}(+)$ patients.
\end{abstract}

HIV AIDS Rev 2018; 17, 3: 159-163 DOI: https://doi.org/10.5114/hivar.2018.78484

Key words: HIV, cardiovascular risk, lipid profile, diet therapy, antiretroviral therapy.

\section{Introduction}

Highly active antiretroviral therapy (HAART) has reduced the number of acquired immune deficiency syndrome (AIDS) diagnoses and extended lives of seropositive patients. Human immunodeficiency virus (HIV)-infected people are now able to reach old age [1]. Similarly to the general population, controlling civilizational and metabolic diseases, especially cardiovascular disease $(\mathrm{CD})$, which increase the risk of early death but are not directly associated with AIDS, has become a clinical problem [2].
Although extremely effective at combatting AIDS, antiretroviral drug (ARV) therapy can still have side effects, including metabolic disorders [3]. Adverse effects of combined antiretroviral therapy (cART) on lipid profile are well known [4]. They manifest as increased triglycerides, total and LDL cholesterol levels, as well as decreased HDL cholesterol levels [5]. The pathomechanism of these changes is complex, and one of the postulated factors is mitochondrial toxicity [2]. Viral replication can also modulate lipid and lipoprotein concentrations and accelerates the development of arterial disease [3].
Address for correspondence: Prof. Brygida Knysz, Department of Infectious Diseases, Liver Diseases and Acquired Immune Deficiences, Wroclaw Medical University,

5 Koszarowa St., 51-171 Wrocław, Poland,

e-mail: brygida.knysz@gmail.com
Article history:

Received: 15.02 .2018

Received in revised form: 12.04.2018

Accepted: 30.04.2018

Available online: 15.08 .2018
International Journal of HIV-Related Problems

HIV \& AIDS $R$ e $v$ i e w 
Comprehensive care for patients with lipid disorders, especially $\mathrm{HIV}(+)$ patients, requires a multi-pronged approach as well as lifestyle changes, including proper diet and pharmacological treatment. Improving lipid profile through lifestyle modification, particularly by following a diet plan, could limit the need for additional pharmacotherapy and minimise the risk of drug-drug interactions or other undesired effects $[3,6]$.

\section{Risk factors for cardiovascular disease}

Besides classical risk factors of cardiovascular disease, $\mathrm{HIV}$ is an additional factor raising the risk by causing persistent immune activation and enhancing atherogenesis [7, 8].

\section{Hypercholesterolaemia in HIV-positive individuals}

Based on the NATPOL 2002 and 2011 studies, the prevalence of hypercholesterolaemia in the Polish population (aged 18-79 years) reached levels as high as 61\% (approximately 18 million people).

Attention has also been drawn to the unfavorable phenomenon of the falling percentage of people in Poland with high HDL levels. Very low HDL levels have been reported in WOBASZ study of the general population and among HIV positive persons not on CART from POLCA cohort [9]. In other countries elevated LDL was reported in 35\% of patients [10]. Hypercholesterolemia is more commonly observed among patients on cART and depends on the class of drugs used [11]. Particularly protease inhibitors (PIs) such as indinavir and lopinavir increase LDL and HDL cholesterol levels. In this class of drugs only atazanavir is associated with minor changes in lipid profile [12]. Among Polish patients treated with antiretroviral drugs, abnormal levels of total and LDL cholesterol were $37 \%$ and $47 \%$, respectively [9].

\section{Hypertriglyceridaemia in HIV-positive patients}

Hypertriglyceridaemia was seen in $20 \%$ of women and $31 \%$ of men in the WOBASH population [13]. In the SCOLTA project, it was noted that this relationship, where men were more likely to develop hypertriglyceridemia, can also be attributed to the HIV population [14]. The exact pathomechanism linking hypertriglyceridaemia with cardiovascular risk is still being investigated [15]. As with hypercholesterolaemia, hypertriglyceridaemia is dependent on the class of drugs and, in the case of the combined use of nucleoside reverse transcriptase inhibitors (NRTIs) with PIs, its prevalence reaches almost $60 \%$ [16]. A positive note from the study is that among patients undergoing dietary intervention only $16 \%$ of seropositive individuals developed hypertriglyceridaemia, compared to $50 \%$ of those without dietary intervention [17]. Among Polish $\mathrm{HIV}(+)$ patients receiving antiretroviral therapy the prevalence of hypertriglyceridaemia can reach as much as $48 \%$ [9]. It is worth pointing out that some PI-based therapies can induce or exacerbate hypertriglyceridaemia. Non-nucleoside reverse transcriptase inhibitor (NNRTIs) therapy also significantly increases serum triglyceride levels, but to a lesser extent than PIs [18].

\section{Metabolic syndrome}

Decreased HDL cholesterol and elevated triglyceride levels may be part of metabolic syndrome (MS) [10]. Low HDL cholesterol level and insulin resistance are consequences of consuming excessive amounts of easily digestible carbohydrates. Abdominal obesity (waist circumference $>88 \mathrm{~cm}$ for women and $>94 \mathrm{~cm}$ for men in the European population) [19] with insulin resistance play an important role in the development of MS; therefore, weight reduction is very important. Many studies have shown that elevated HDL cholesterol levels are associated with weight loss [20, 21].

It was observed by Mondy et al. that the incidence of metabolic syndrome was similar in HIV-infected patients and in a healthy NHANES group [22]. Other studies conducted with $\mathrm{HIV}(+)$ and non-infected individuals from different parts of the world have shown that MS is significantly more common in HIV-infected patients [23].

Some studies evaluating the incidence of metabolic syndrome in the HIV-infected population showed lopinavir/ ritonavir (PI), indinavir/ritonavir (PI), and stavudine (NRTI) as factors associated with MS [23]. Indinavir and stavudine are no longer used in Poland.

\section{Reduction of cardiovascular risk}

Recommended procedures for people with lipid disorders have been published in the Report of the National Cholesterol Education Program (NCEP), known as the Adult Treatment Panel III [ATP III] [20]. A group of researchers from the Cardiovascular Subcommittee of the AIDS Clinical Trials Group adjusted recommendations for HIV-infected patients. Special attention has been placed on preventive actions aimed at reducing cardiovascular risk. $\mathrm{HIV}(+)$ individuals should be evaluated and treated according to NCEP ATP III guidelines, with particular emphasis on potential drug interactions with cART and maintenance of HIV virological control [10]. In addition, the Polish Forum for Prevention of Cardiovascular Diseases (PFP) recommends implementation of nonpharmacological intervention including diet changes, increased physical activity, weight loss, and quitting smoking in patients with dyslipidaemia [21]. Moreover, the European AIDS Clinical Society (EACS) recommends lifestyle modifications (diet changes, regular exercise, smoking cessation, etc.) in order to improve lipid profile. If these changes are unsuccessful, consideration should be given to cART modification and introduction of lipid-lowering drugs [24].

\section{Treatment of hypercholesterolaemia}

Non-pharmacological interventions are essential for hypercholesterolaemia management and should be imple- 
mented before drug therapy, except when there is an urgent need for pharmacotherapy $[10,25]$. LDL cholesterol level is highly dependent on nutrition and increases when nutrients such as saturated fatty acids (SFA), trans isomers of unsaturated fatty acids, and cholesterol are consumed. LDL cholesterol levels decrease when monounsaturated fatty acids (MUFA) and omega-3 fatty acids are introduced, dietary fibre intake (soluble fraction) is increased, plant stanols are supplemented, dietary intake of cholesterol is reduced, and weight loss is achieved $[17,20,21]$.

The most important dietary intervention is to reduce the intake of SFA and trans isomers. Saturated fatty acids intake should be reduced to $7 \%$ of required energy needs, while cholesterol should not exceed 200 milligrams per day for those who need to lower their LDL cholesterol levels. Metaanalysis of intervention studies shows that following adherence to these recommendations in the general population can reduce LDL cholesterol by an average of $16 \%[20,21]$.

Dietary intervention is particularly recommended for HIV-infected individuals who need to lower their lipoprotein levels, as well as weight [10]. Studies have found that proper diet and regular exercise result in a statistically significant $11 \%$ reduction in cholesterol levels in HIV-infected patients $[10,26]$.

One randomised study looked into the effect of dietary intervention for the prevention of dyslipidaemia in HIV-1 infected patients on HAART. The best results were achieved in the group with dietary intervention with reduced calories, cholesterol, and fat intake (mainly SFA) along with increased carbohydrate and dietary fibre intake. At the end of a one-year period, hypercholesterolaemia was diagnosed in 14 (39\%) patients from the control group and only three (7\%) from the study group [17] (Figure 1).

A different study evaluated the effect of omega-3 fatty acids supplementation on lipid profile in HIV-positive patients and did no show statistically significant changes in LDL and HDL cholesterol levels [27]. A lack of significant changes in total cholesterol levels was observed in both the study population and in non-infected individuals. In addition, LDL-cholesterol and HDL cholesterol increased by $5-10 \%$ and $1-3 \%$, respectively. Therefore, it could be assumed that the use of omega- 3 acids did not result in the expected reduction in total and LDL-cholesterol, and in the case of HDL cholesterol the increases were not significant [28].

On the other hand, a lipid-lowering diet that entails reducing cholesterol intake to 300 milligrams a day, decreasing energy value of meals, replacing animal fats with vegetable fats, and introducing dietary fibre [28] in combination with physical exercise (for example three times a week) showed success by significantly reducing total cholesterol levels by $18 \%[10,26]$.

\section{Treatment of hypertriglyceridaemia}

As in the case of hypercholesterolaemia management with dietary therapy should also be the first-line interven- tion. Elevated triglycerides levels should prompt diet modification. One study has shown that adherence to a recommended diet is beneficial for triglyceride levels, reducing them by $23 \%$ in six months. Dietary counselling combined with supervised exercise three times a week and cycling reduced triglyceride levels by $25 \%$ [10].

Smoking cessation also helps to lower triglyceride levels and improve the overall risk of cardiovascular disease. Therefore, physical activity, smoking cessation, and weight reduction in obese patients should be encouraged [10].

Irrespective of the cause of hypertriglyceridaemia, which may be endogenous (elevated VLDL-TG levels) or exogenous (increased chylomicron triglycerides levels), an important component of diet therapy is to limit or completely eliminate alcohol intake because it is a potent agent of hypertriglyceridaemia [20].

Patients with hypertriglyceridaemia should reduce their intake of fat and highly processed products and increase their intake of complex carbohydrates, including dietary fibre. Restrictions should be made on the consumption of easily digestible carbohydrates such as sucrose and fructose, which are substrates for triglyceride synthesis in the liver. This in effect leads to a decrease in triglycerides and HDL cholesterol levels $[17,20]$.

It is additionally important to replace saturated fatty acids and monounsaturated fatty acids with polyunsaturated omega-3 fatty acids. As recommended by the Consensus of the Editorial Board of the Polish Forum for Prevention of Cardiovascular Diseases, on the principles of proper nutrition, an $n-6 / n-3$ fatty acid ratio of $4: 1$ should be provided $[29,30]$. Large amounts of omega-3 fatty acids (EPA and DHA) are present in fresh, greasy fish and vegetable oils (mainly flaxseed oil and cold pressed rapeseed oil). It is recommended 2-4 $\mathrm{g}$ of these fatty acids be ingested daily, for example in the form of fish oil supplements [20]. The mechanism by which omega-3 fatty acids cause a decrease in tri-

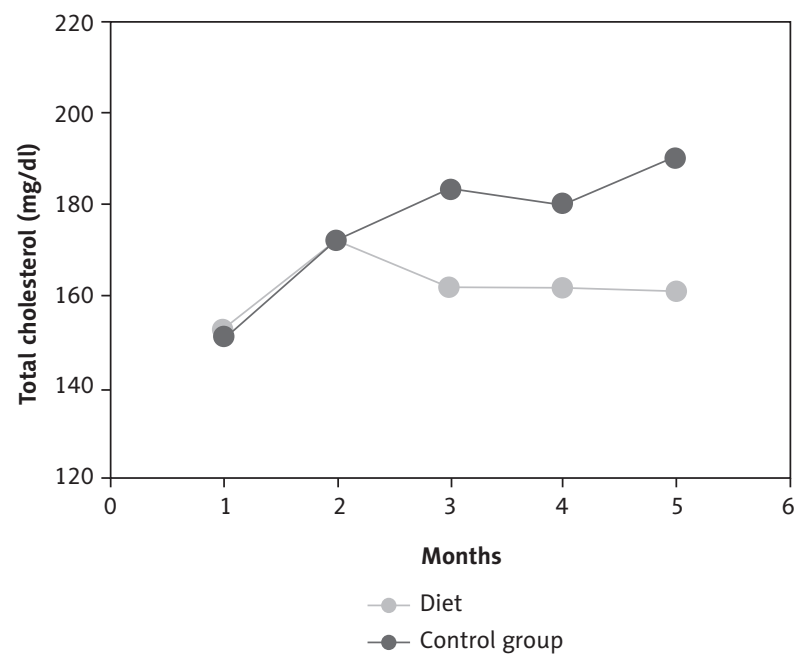

Fig. 1. Effect of 12-month dietary intervention on total cholesterol concentration (mg/dl) [17] 


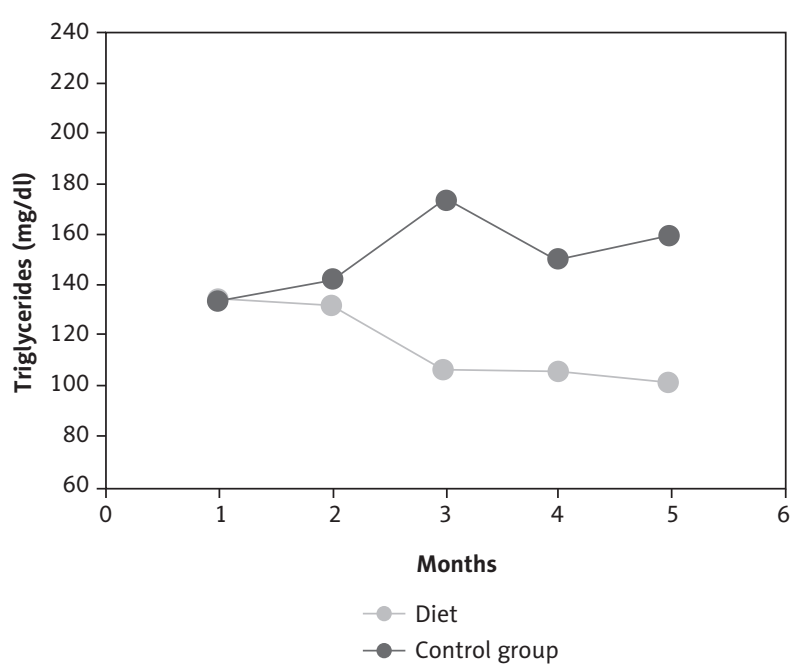

Fig. 2. Effect of 12-month dietary intervention on triglyceride concentration (mg/dl) [17]

glyceride levels is probably related to inhibition of enzymes involved in TG synthesis in the liver, competition between fatty acid oxidation and triglyceride biosynthesis, and increased triglyceride clearance due to endogenous lipoprotein lipase activity stimulation [24].

Severe hypertriglyceridaemia and hyperchylomicronaemia require low dietary fat content (less than 30\% of energy intake, including < 7\% SFA) [20], avoidance of simple sugars, and reduction or elimination of alcohol consumption. In cases where triglyceride levels are extremely high $(>2000 \mathrm{mg} / \mathrm{dl}$ or $>1000 \mathrm{mg} / \mathrm{dl}$ in patients with pancreatitis) it is justified to use nonpharmacological intervention together with pharmacotherapy $[10,20]$.

Omega-3 fatty acids as well as fibrates and statins significantly reduce triglyceride levels. Delivering high doses of omega- 3 fatty acids is associated with a decrease in TG levels of between $25 \%$ and $30 \%$. Statins and fibrates reduce TG concentrations by $7 \%$ to $30 \%$ and by $20 \%$ to $50 \%$, respectively. The greatest reduction was seen among people with advanced hypertriglyceridaemia. Numerous studies have shown measurable benefits from incorporating omega-3 supplementation into pharmacotherapy [27] also in the HIV population [25, 28, 31-34]. However, benefits of supplementation have not been established for protease inhibitors [10]. The importance of dietary intervention in terms of maintaining normal levels of triglycerides in $\mathrm{HIV}(+)$ patients can also be seen in a study from southern Brazil [17] (Figure 2).

The key approach to controlling triglyceride levels in $\mathrm{HIV}(+)$ patients should include dietary changes and increased physical activity and in certain cases fibrate therapy and omega-3 supplementation [24].

\section{Mediterranean diet}

A Mediterranean diet contains a small amount of saturated fatty acids ( $\leq 7-8 \%$ energy) and is characterised by high intake of olive oil, vegetables, fruit, grain products, and legumes, average consumption of milk products, alcohol, and fish, and low intake of animal fat and meat. The rule is to create a diet from products available on the local market that will be rich in monounsaturated fatty acids, omega- 3 fatty acids, antioxidant vitamins, flavonoids, and fibre and low in saturated fatty acids and cholesterol [34].

One of the studies has shown that consumption of olive oil and nuts reduces LDL cholesterol levels and therefore atherosclerosis risk [35]. The effectiveness of the Mediterranean diet in terms of cardiovascular risk reduction was also examined among HIV-infected people during the first year of HAART. The study did not show a statistically significant difference between serum lipids levels and compliance with the Mediterranean diet. Consumption of olive oil was not associated with a decrease in lipid levels, and moderate alcohol consumption had no effect on total cholesterol, LDL cholesterol, and triglycerides. Similar results were obtained in the healthy population. It is thought that the protective effect of a Mediterranean diet is not related to total plasma cholesterol, LDL, and HDL cholesterol but with changes observed in fatty acid concentrations. Controlled dietary studies have shown that a Mediterranean diet in which the consumption of MUFA and PUFA (polyunsaturated fatty acids) was relatively high lowered LDL cholesterol and TG levels and increased HDL cholesterol levels. In addition, randomised trials have shown that patients on PI-containing cART using pravastatin and dietary advice tend to have lower cholesterol levels, while diet only did not affect lipid levels [36].

\section{Conclusions}

Dietary counselling for HIV-infected people is effective and can bring measurable benefits: it can significantly reduce total cholesterol and increase HDL cholesterol levels, thus reducing cardiovascular risk. Monitoring of lipid parameters by diet can help to avoid pharmacological therapy and the risk of interactions with cART.

Supplementation with omega-3 fatty acids seems to be advantageous due to their ability to reduce serum triglyceride levels.

In view of the benefits that can be gained by people living with HIV from dietary intervention, it is appropriate to include dieticians in the panel of specialists who take care of $\mathrm{HIV}(+)$ patients.

\section{Conflict of interest}

The authors declare no potential conflicts of interest with respect to the research, authorship, and/or publication of this article.

\section{References}

1. Montaner J, Lima V, Harrigan R, et al. Expansion of HAART coverage is associated with sustained decreases in HIV/AIDS morbidity, 
mortality and HIV transmission: The "HIV Treatment as Prevention" experience in a Canadian setting. PLoS One 2014; 9: e87872.

2. Deeks SG, Tracy R, Douek DC. Systemic effects of inflammation on health during chronic HIV infection. Immunity 2013; 39: 633645.

3. Corkery S, Hughson G. Side-effects. 2013. Available at: http://www. aidsmap.com/Side-effects/page/1283774/ (Accessed: October 2017).

4. Palios J, Kadoglou NP, Lampropoulos S. The pathophysiology of HIV-/HAART-related metabolic syndrome leading to cardiovascular disorders: the emerging role of adipokines. Exp Diabetes Res 2012; 2012: 103063.

5. Jankowska M, Lemańska M, Dręczewski M. Interakcje lekowe. In: Zasady opieki nad osobami zakażonymi HIV. Zalecenia PTN AIDS. Horban A, Podlasin R, Cholewińska G et al. Polskie Towarzystwo Naukowe AIDS, Warszawa-Wrocław 2017; 92-107.

6. Alcorn K, Corkery S, Hughson G. Anti-HIV drugs. 2014. Available at: http://www.aidsmap.com/Anti-HIV-drugs/page/1060104/.

7. Graham I, Atar D, Borch-Johnsen K, et al. Europejskie wytyczne dotyczące prewencji chorób sercowo-naczyniowych w praktyce klinicznej - wersja skrócona. Kardiol Pol 2008; 66 (Suppl 4): 1-48.

8. Sereti I, Altfeld M. Immune activation and HIV: An enduring relationship. Curr Opin HIV AIDS 2016; 11: 129-130.

9. Kwiatkowska W, Bogdański P, Pulik P, et al. Postępowanie profilaktyczne, diagnostyczne i lecznicze w chorobach układu sercowo-naczyniowego u osób zakażonych HIV. In: Zasady opieki nad osobami zakażonymi HIV. Zalecenia PTN AIDS. Horban A, Podlasin R, Cholewińska G, et al. Polskie Towarzystwo Naukowe AIDS, Warszawa-Wrocław 2017; 386-394.

10. Dube MP, Stein JH, Aberg JA, et al. Guidelines for the evaluation and management of dyslipidemia in human immunodeficiency virus (HIV)-infected adults receiving antiretroviral therapy: recommendations of the HIV Medical Association of the Infectious Disease Society of America and the Adult AIDS Clinical Trials Group. Clin Infec Dis 2003; 37: 613-627.

11. Bergersen BM. Cardiovascular risk in patients with HIV Infection: impact of antiretroviral therapy. Drugs 2006; 66: 1971-1987.

12. Souza SJ, Luzia LA, Santos SS, et al. Lipid profile of HIV-infected patients in relation to antiretroviral therapy: a review. Rev Assoc Med Bras (1992) 2013; 59: 186-198.

13. Pająk A, Wiercińska E, Polakowska M, et al. Rozpowszechnienie dyslipidemii u mężczyzn i kobiet w wieku 20-74 lat w Polsce. Wyniki programu WOBASZ. Kardiol Pol 2005; 63 (supl. 4).

14. Menzaghi B, Ricci E, Vichi F, et al. Gender differences in HIV infection: Is there a problem? Analysis from the SCOLTA cohorts. Biomed Pharmacother 2014; 68: 385-390.

15. Wożakowska-Kapłon B, Barylski M, Slawa P, et al. Zalecenia postępowania w dyslipidemii - propozycje algorytmu dla lekarzy rodzinnych. 2012. Available at: http://czasopisma.viamedica.pl/fmr/ article/viewFile/20412/18702 (Accessed: 2 May 2014).

16. Knudsen A, Kristoffersen US, Kjaer A, et al. Cardiovascular Risk in Patients with HIV Infection. Future Virology 2012; 7: 413-423.

17. Lazzaretti RK, Kuhmmer R, Sprinz E, et al. Dietary intervention prevents dyslipidemia associated with highly active antiretroviral therapy in human immunodeficiency virus type 1-infected individuals. J Am Coll Cardiol 2012; 59: 979-988.

18. Feeney ER, Mallon PW. HIV and HAART-Associated Dyslipidemia. Open Cardiovasc Med J 2011; 5: 49-63.

19. International Diabetes Federation (2017). The IDF consensus worldwide definition of the metabolic syndrome. Available at: https://www. idf.org/e-library/consensus-statements/60-idfconsensus-worldwide-definitionof-the-metabolic-syndrome.

20. National Cholesterol Education Program (NCEP) Expert Panel on Detection, Evaluation, and Treatment of High Blood Cholesterol in Adults (Adult Treatment Panel III). Third Report of the National Cholesterol Education Program (NCEP) Expert Panel on Detection, Evaluation, and Treatment of High Blood Cholesterol in
Adults (Adult Treatment Panel III) final report. Circulation 2002; 106: 3143-1421.

21. Cybulska B, Szostak W, Podolec P. Konsensus Rady Redakcyjnej PFP dotyczący dyslipidemii. Available at: http://www.pfp.edu.pl/ download/forum11.pdf.

22. Mondy K, Overton ET, Grubb J, et al. Metabolic Syndrome in HIV-Infected Patients from an Urban, Midwestern US Outpatient Population. Clin Infect Dis 2007; 44: 726-734.

23. Pao V, Lee GA, Grunfeld C. HIV therapy, metabolic syndrome, and cardiovascular risk. Curr Atheroscler Rep 2008; 10: 61-70.

24. Stradling C, Chen Y, Russell T. Omega-3 Fatty Acids and Hypertriglyceridemia in HIV-Infected Subjects on Antiretroviral Therapy: Systematic Review and Meta-analysis. 2012. Available at: http://aidsinfo.nih.gov/guidelines/html/1/adult-and-adolescentarv-guidelines/31/adverse-effects-of-antiretroviral-agents.

25. Mannu GS, Zaman MJ, Gupta A, et al. Evidence of lifestyle modification in the management of hypercholesterolemia. Curr Cardiol Rev 2013; 9: 2-14.

26. Jones SP, Doran DA, Leatt PB, et al. Short-term exercise training improves body composition and hyperlipidaemia in HIV-positive individuals with lipodystrophy. AIDS 2001; 15: 2049-2051.

27. Thusqaard M, Christensen JH, Morn B, et al. Effect of fish oil (n-3 polyunsaturated fatty acids) on plasma lipids, lipoprotein and inflammatory markers in HIV-infected patients treated with antiretroviral therapy: A randomized, double-blind, placebo-controlled study. Scand J Infect Dis 2004; 41: 760-766.

28. Harris WS. n-3 fatty acids and serum lipoproteins: human studies. Am J Clin Nutr 1997; 65 (5 Suppl): 1645S-1654S.

29. Mojska H, Kłosiewicz-Latoszek L, Jasińska-Melon E, et al. Kwasy tłuszczowe omega-3. In: Normy żywienia dla populacji polskiej. Jarosz M (ed.). Instytut Żywności i Żywienia, Warszawa 2017; 76-87.

30. Myerson M, Poltavskiy E, Armstrong EJ, et al. Prevalence, treatment and control of dyslipidemia and hypertension in 4278 HIV outpatients. J Acquir Immune Defic Syndr 2014; 66: 370-377.

31. Peters BS, Wierzbicki AS, Moyle G, et al. The effect of a 12-week course of omega-3 polyunsaturated fatty acids on lipid parameters in hypertriglyceridemic adult $\mathrm{HIV}$-infected patients undergoing HAART. Clin Ther 2012; 34: 67-76.

32. Gerber JG, Kitch DW, Fichtenbaum CJ, et al. Fish oil and fenofibrate for the treatment of hypertriglyceridemia in HIV infected subjects on antiretroviral therapy: results of ACTG A5186. J Acquir Immune Defic Syndr 2008; 47: 459-466.

33. Vieira AD, Silveira GR. Effectiveness of n-3 fatty acids in the treatment of hypertriglyceridemia in HIV/AIDS patients: a meta-analysis. Cien Saude Colet 2017; 22: 2659-2669.

34. Cichocka A. Dieta śródziemnomorska w profilaktyce pierwotnej choroby niedokrwiennej serca. Endokrynologia, Otyłość i Zaburzenia Przemiany Materii 2005; 1: 30-36.

35. Hernáez Á, Castañer O, Goday A, et al. The Mediterranean Diet decreases LDL atherogenicity in high cardiovascular risk individuals: a randomized controlled trial. Mol Nutr Food Res 2017; 61; doi: 10.1002/mnfr.201601015.

36. Turcinov D, Stanley C, Canchola J, et al. Dyslipidemia and adherence to the Mediterranean diet in Croatian HIV-infected patients during the first year of highly active antiretroviral therapy. Coll Antropol 2009; 33: 423-430. 